\title{
Loss of Fas (CD95/APO-1) Regulatory Function Is an Important Step in Early MALT-Type Lymphoma Development
}

\author{
Harald Seeberger, Petr Starostik, Stephan Schwarz, Constanze Knörr, Jörg Kalla, \\ German Ott, Hans Konrad Müller-Hermelink, and Axel Greiner \\ Institute of Pathology, University of Würzburg, Würzburg, Germany
}

\begin{abstract}
SUMMARY: Fas (CD95, APO-1) mutations were found in autoimmune diseases and some lymphomas, suggesting impairment of Fas-mediated cell death signaling that may cause tumor development. Because mucosa-associated lymphoid tissue (MALT)-type lymphoma B cells recognize autoantigens and proliferate in response to antigen and T cell-mediated signals, it is suggestive that autoreactive B cell lymphoma precursor cells may have escaped the Fas-mediated checkpoint that normally operates in healthy individuals. Using different biochemical, molecular, and functional approaches, we analyzed the Fas signaling in malignant B cells from seven MALT-type lymphomas that were additionally characterized for the $t(11 ; 18)(q 21 ; q 21)$ and four gastric diffuse large B cell lymphomas (DLBL). All DLBLs and three of seven MALT-type lymphomas were resistant to Fas-mediated apoptosis in vitro. Moreover, four of five MALT-type lymphomas analyzed and one of three DLBLs analyzed showed mutations in Fas mRNA transcripts but no loss of heterozygosity in the Fas promotor region. Alternative mechanisms of resistance to apoptosis, such as decreased expression of Fas or production of soluble Fas were not operative. Therefore, it is suggestive that a subgroup of MALT-type lymphoma B cells, irrespective of $\mathrm{t}(11 ; 18)(\mathrm{q} 21 ; \mathrm{q} 21)$, escape the censoring Fas pathway by mutating and inactivating Fas. This identifies a key regulatory step in early MALT-type lymphomagenesis. (Lab Invest 2001, 81:977-986).
\end{abstract}

$M$ arginal zone B cell lymphomas of mucosaassociated lymphoid tissue (MALT)-type are neoplastic counterparts of normal memory B cells (Harris et al, 1994). The development from naive to memory B cells is closely accompanied and regulated by $T$ cells through Fas/FasL interaction (Nagata, 1997; Suda et al, 1993) taking place in the germinal centers of follicles and leading either to deletion of autoantigen-recognizing $B$ cells or to further differentiation into memory B cells resident in the marginal zone of the follicle (Goodnow, 1996; Rathmell et al, 1996) and plasma cells. Therefore, disruption of the Fas/FasL apoptotic pathway is associated with lymphoproliferative and autoimmune disorders as demonstrated in mice carrying lymphoproliferation (lpr) or generalized lymphoproliferative disease (gld) mutations affecting the genes for Fas and FasL, respectively (Takahashi et al, 1994; Watanabe-Fukunaga et al, 1992), or in humans carrying inherited mutations in the Fas gene leading to autoimmune lymphoproliferative syndrome (Bettinardi et al, 1997; Fisher et al, 1995; Rieux Laucat et al, 1995; Sneller et al, 1997). Because autoantigen receptors and marginal zone $B$ cell expansions are characteristic features of MALT-type lymphoma (Greiner et al, 1998), we searched for a link between tumor

Received March 20, 2001.

This work was supported by Interdisziplinären Zentrum für Klinische Forschung der Universität Würzburg (IZKF Wïrzburg), Grant B3, and Wilhelm-Sander-Stiftung, Grant 94.025.3.

Address reprint requests to: Dr. Axel Greiner, Institute of Pathology, University of Wïrburg, Josef-Schneider-Strasse 2, D-97080 Wïrburg, Germany.E-mail:path040@mail.uni-wuerzburg.de development and functionality of the Fas/FasL apoptotic pathway. In addition, the translocation $\mathrm{t}(11 ; 18)(\mathrm{q} 21 ; \mathrm{q} 21)$ is the most characteristic chromosomal aberration in extranodal MALT-type lymphoma and may interfere with the regulation of apoptosis. In recent studies, the gene for the human inhibitor of apoptosis protein-1 (HIAP-1) on chromosome 11 was identified as being directly affected by this translocation (Dierlamm et al, 1999). The protein HIAP-1 has been implicated in Fas-induced apoptosis and other death pathways by direct inhibition of some caspases (Deveraux and Reed, 1999; Deveraux et al, 1998; Roy et al, 1997).

Therefore, the malfunction of apoptosis could explain the insensitivity of malignant B cells toward T cell control that may exist in vitro and in vivo (Greiner et al, 1997; Hussell et al, 1996; Knörr et al, 1999). In our study, we measured $\mathrm{T}$ cell-induced, Fas-mediated apoptosis in malignant $B$ cells in vitro and compared it with normal memory B cells under the same experimental conditions. We found that resistance to Fas-mediated apoptosis characterizes certain MALT-type lymphomas, and we further examined the mechanisms underlying this phenomenon.

\section{Results}

Malignant B Cells of MALT-Type Lymphoma, but Not DLBL, Show Reduced Fas Expression Compared with Normal Memory B Cells

Considering a potential Fas/FasL interaction between $B$ and $T$ cells, we first determined basal Fas 
expression by FACS analysis of freshly isolated malignant $B$ cells from the investigated cases of MALT-type lymphoma and compared it with that of normal memory B cells. Basal Fas expression of normal memory B cells was found to be moderate (mean fluorescence intensity [MFI], 22; Fig. 1A). However, malignant B cells of MALT-type lymphoma differed: four cases had very low Fas expression (mean $\mathrm{MFI}, 4$ ) and three cases showed low Fas expression (mean MFI, 10). In contrast, malignant $B$ cells from diffuse large $B$ cell lymphoma (DLBL) exhibited a very heterogenous Fas expression, ranging from MFI 15 to MFI 55 (mean MFI, 33).

Next, we cocultured $B$ cells with activated $T$ cells for 24 hours and again determined Fas expression of B cells. Normal memory B cells increased Fas expression more than twofold (MFI, 52) under these conditions. A similar inducibility of Fas expression was also found in malignant B cells from MALT-type Iymphoma. But here the absolute values of expression were markedly lower (mean MFI, 17 and 23, respectively). In contrast, Fas expression of malignant B cells from DLBL was only slightly enhanced by activated $\mathrm{T}$ cells.

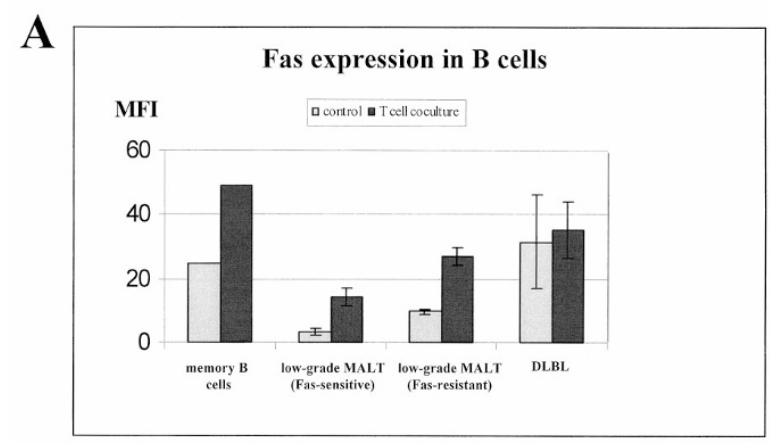

C
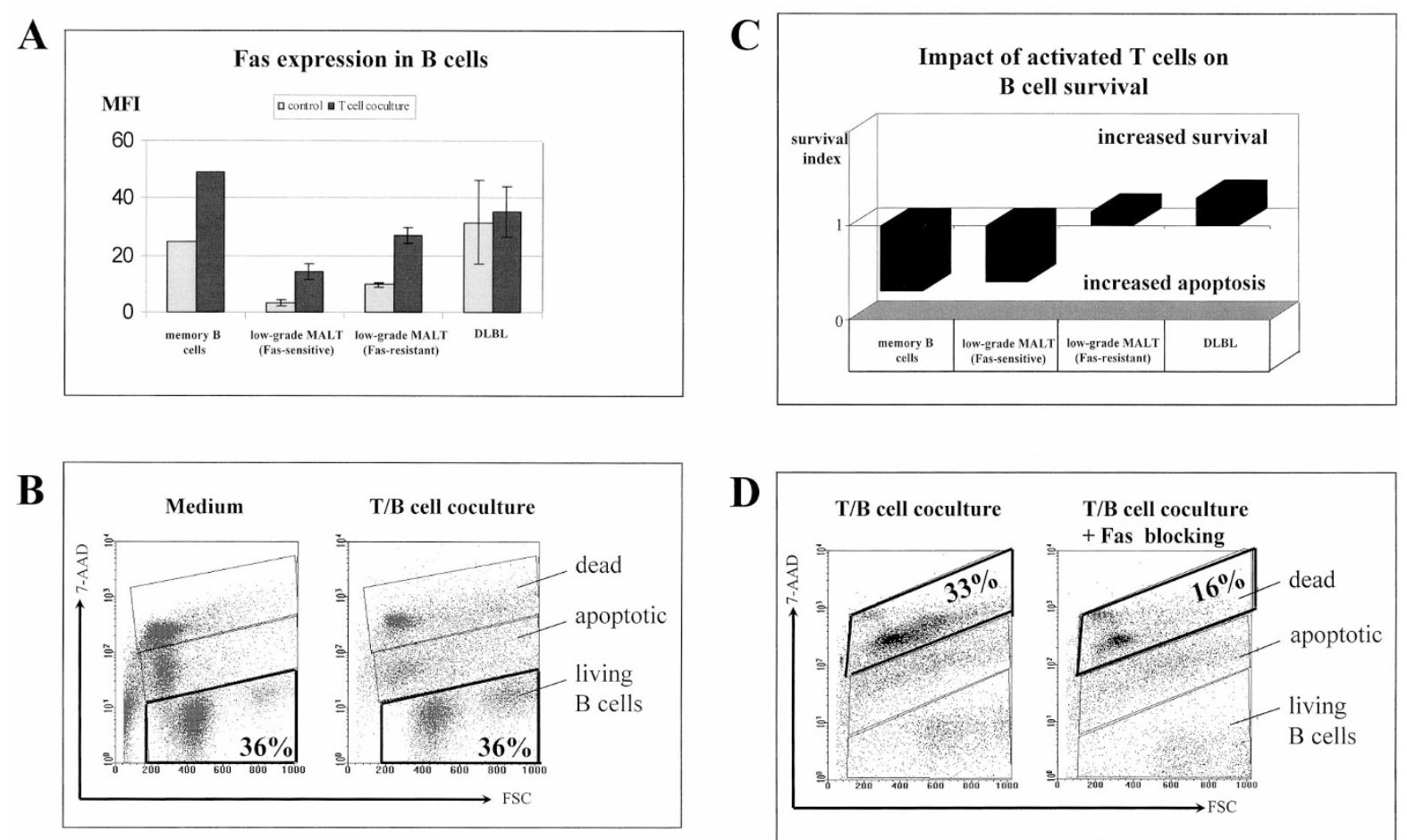

D

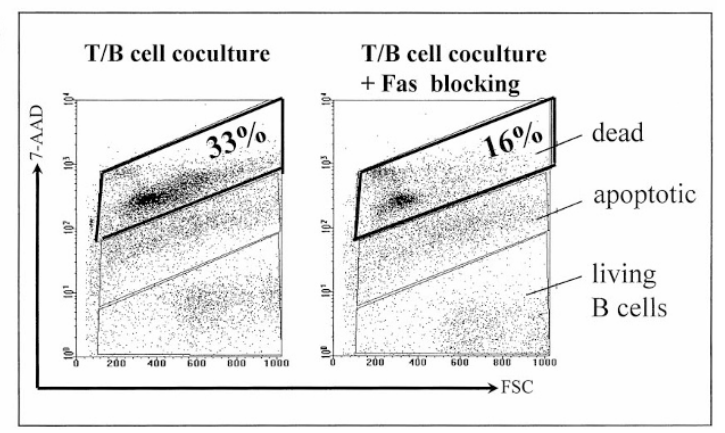

Figure 1.

Influence of activated T cells on Fas expression and survival of malignant B cells from mucosa-associated lymphoid tissue (MALT) lymphoma. A, Activated T cells enhance Fas expression markedly in normal memory B cells and malignant B cells from MALT-type lymphoma (four cases were Fas-sensitive, three cases Fas-resistant), but only slightly in malignant B cells from four cases of diffuse large B cell lymphoma (DLBL) as determined by FACS analysis. MFI, mean fluorescence intensity. Error bars indicate standard deviation of MFI. B, The number of living B cells from a Fas-resistant MALT-type lymphoma (Case 5) is not reduced by T cell influence as measured by FACS analysis of B cells stained with 7-amino actinomycin D (7-AAD). FSC, forward scatter. C, The summary of our findings shows that activated T cells induce apoptosis only in normal memory B cells and in malignant B cells from a subgroup of MALT-type lymphomas (four out of seven cases), indicated as Fas-sensitive. Survival index: percentage of surviving B cells in T cell coculture/percentage of surviving B cells without coculture. D, The contro experiment demonstrates that apoptosis is Fas-mediated because Fas-sensitive malignant B cells (Case 3 ) can be rescued from apoptosis in the presence of an antibody (ZB 4) that blocks the Fas molecule, as measured in FACS analysis of B cells stained with 7-AAD. 


\section{Caspases-3 and -8 Are Present in Malignant B Cells Resistant to Apoptosis}

We examined poly-ADP ribose polymerase (PARP)cleavage, a hallmark of apoptosis, by Western blotting and found in normal B cells two bands corresponding to intact and cleaved PARP, both without and with $\mathrm{T}$ cell coculture. In Fas-resistant malignant $B$ cells, PARP-cleavage, but not processing of caspases-3 and -8, was abrogated in T cell coculture (Fig. 2A).

We further looked at additional genes involved in pathways of apoptosis or survival. Using reverse transcription-polymerase chain reaction (RT-PCR), we monitored the expression of genes whose products inhibit apoptosis, such as bcl-2 and bcl-xL, or promote apoptosis, such as bcl-xS, bax, p53, and c-myc.

In normal memory $B$ cells, basal expression of bcl-xL, bcl-2, bax, c-myc, and p53 was enhanced by coculture with activated $T$ cells. In contrast, Fas-resistant malignant $B$ cells showed no detectable expression of bcl- $x \mathrm{~L}$, but they still showed induction of c-myc and p53 (Fig. 2B). Among the Fas-sensitive malignant $B$ cells, two cases out of four showed no detectable c-myc and p53 expression. In conclusion, there was no specific expres- sion pattern that would characterize either Fas-resistant or Fas-sensitive B cells.

\section{Malignant B Cells Produce mRNA for Soluble Fas (sFas), but No Protein}

RT-PCR of the complete coding sequence of Fas yielded not only the expected product of $1008 \mathrm{bp}$ in size, but also a smaller one with $945 \mathrm{bp}$, which was found in two case of Fas-resistant MALT-type lymphoma and in two cases of DLBL (Fig. 3A). Direct sequence analysis of the smaller transcript revealed that it lacked the codons for the transmembrane domain of Fas (Fig. 3B). This mRNA variant was described as coding for soluble Fas (sFas) (Cascino et al, 1995; Cheng et al, 1994). However, we could not detect any sFas protein in cell culture supernatants of malignant B cells by immunoprecipitation and Western blotting (Fig. 3C).

\section{Malignant B Cells Show Mutations in Fas Transcripts but No LOH in the Locus of the Fas Gene}

In further investigations we screened the Fas molecule for mutations. The coding region of Fas was amplified
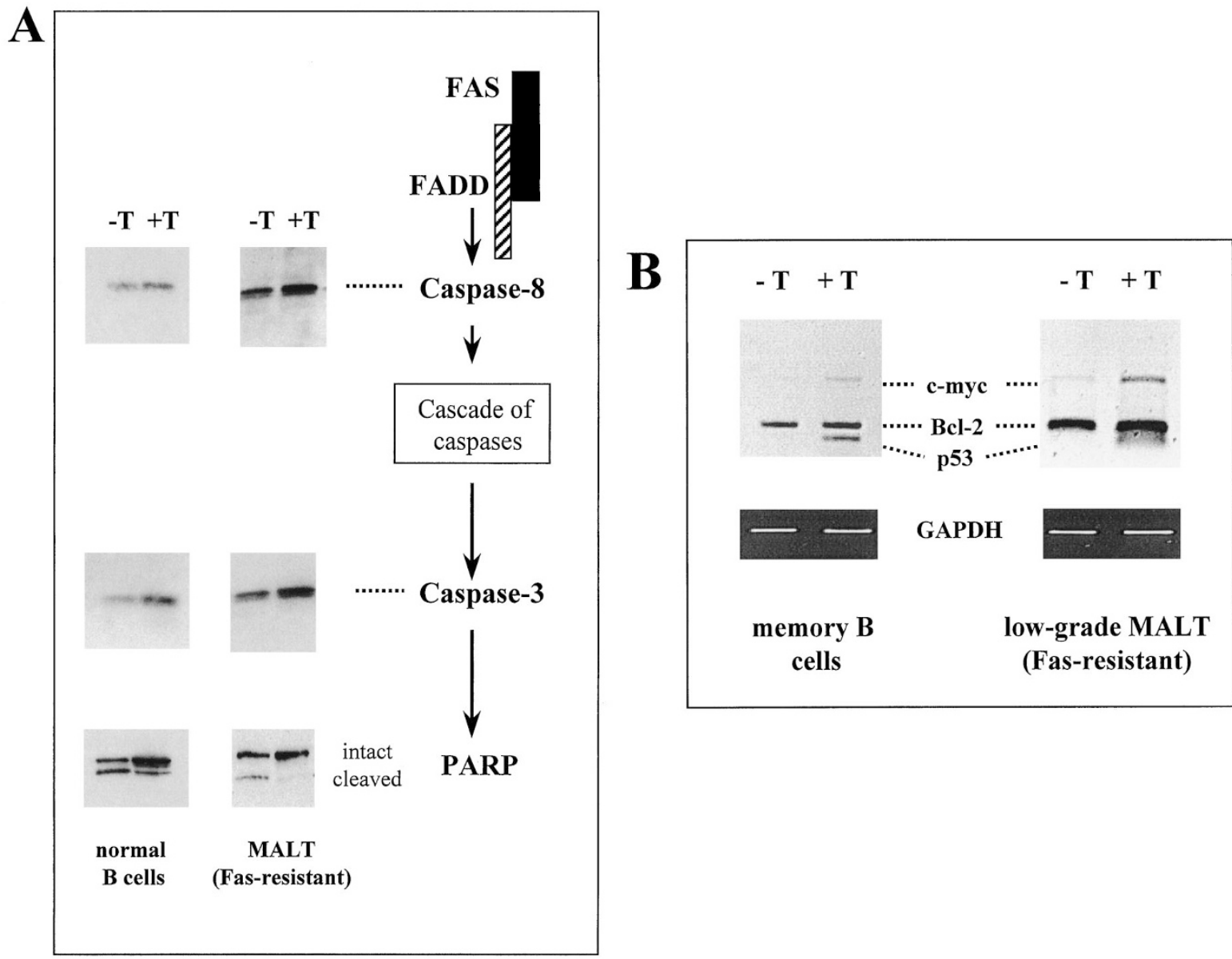

\section{Figure 2.}

A, Caspases-3 and -8 are detected by Western blotting in Fas-resistant malignant B cells (Case 6 ) as well as in normal B cells. However, cleavage of poly-ADP ribose polymerase (PARP) is abrogated by $T$ cell influence only in the malignant B cells. Malignant B cells were either cultured for 24 hours in medium alone (-T) or cocultured with activated T cells $(+\mathrm{T})$ that were removed afterward. B. The expression pattern of c-myc, Bcl-2, and p53 shows no difference between Fas-resistant malignant B cells and normal memory B cells as determined by reverse transcriptase polymerase chain reaction (RT-PCR). GAPDH, glyceraldehyde-3-phosphate dehydrogenase. 


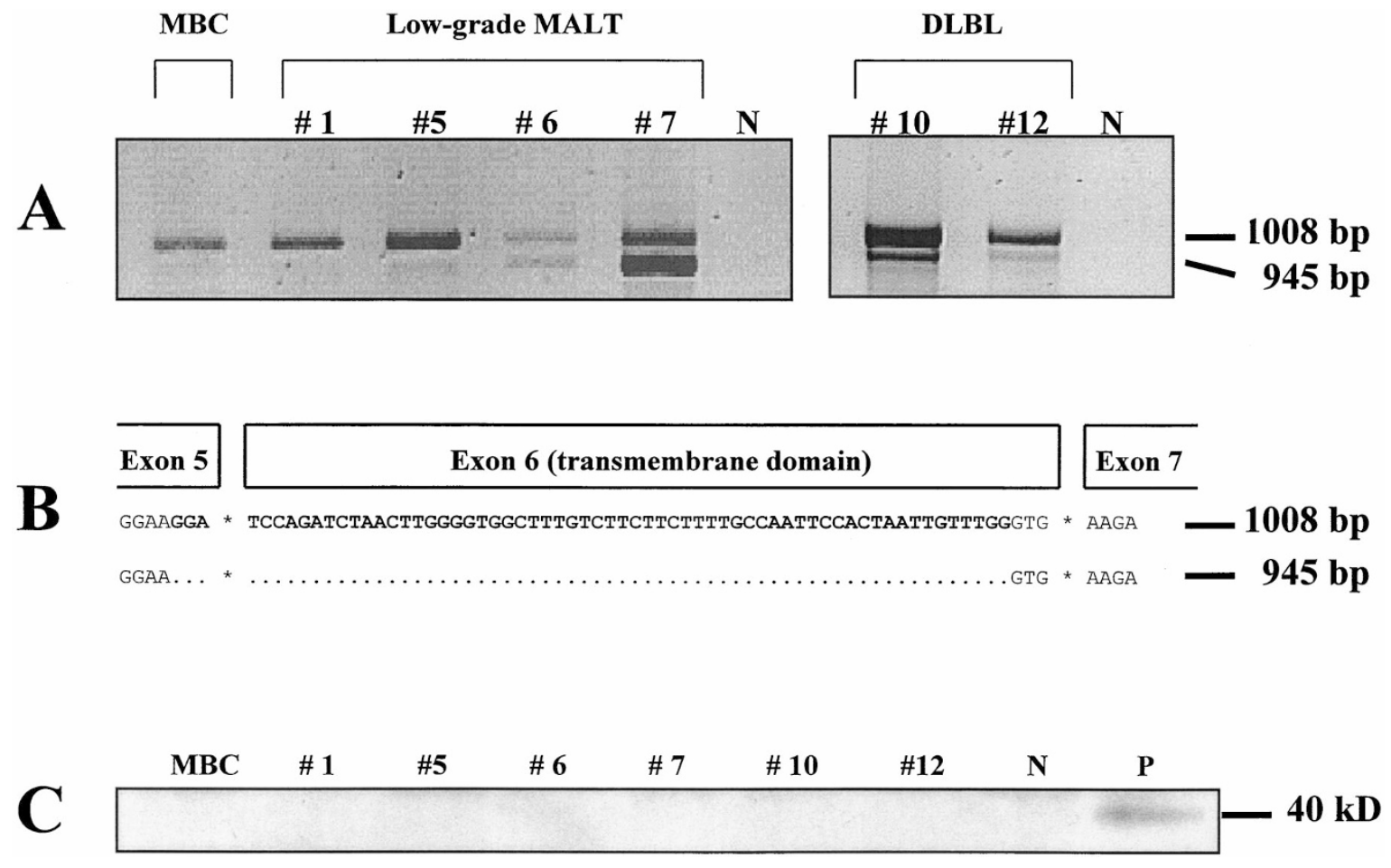

Figure 3 .

Malignant B cells produce soluble Fas (sFas) mRNA, but no protein. A, RT-PCR of the Fas transcript reveals a variant which lacks 63 bp. This variant is found in Fas-resistant MALT-type lymphoma (Cases 5 and 6 ) and DLBL only. MBC, normal memory B cells as control; N, negative control. B, Direct sequence analysis shows that the smaller Fas transcript is a splicing variant lacking exon 6, the transmembrane domain. C, Immunoprecipitation of sFas from cell culture supernatants demonstrates no detectable sFas protein in any of the cases investigated. N, negative control; P, positive control (immunoprecipitation of $100 \mathrm{ng}$ of recombinant human sFas).

using RT-PCR, cloned, and sequenced. Apart from various randomized mutations occurring in only one of the clones, we also found point mutations in two or more independent clones investigated (Fig. 4). For the analysis we focused on the latter and found 10 different point mutations in four MALT-type lymphomas (Cases 1, 5, 6, and 7) and one DLBL (Case 9, Table 1). Case 1 showed one mutation, Cases 5 and 7 two mutations each, and Case 6 four mutations, whereas the DLBL Case 9 possessed three mutations. In particular, the 10 mutations consisted of seven transitions, two transversions, and one 1-bp insertion. Four of the 10-point mutations caused a change in the predicted amino acid sequence at codons 23, 50, 172, and 229 , respectively, whereas four mutations affected the third position of the codons 27, 237, 255, and 291 (silent mutations, Table 1), thus having no relevance for the amino acid sequence. One mutation introduced a premature termination signal after codon 152. The 1-bp insertion caused a frame shift after codon 284, resulting in 19 new amino acids and premature termination thereafter, so that the predicted protein would lack 16 amino acids.

To investigate loss of heterozygosity $(\mathrm{LOH})$ in the Fas gene locus, we used two flanking microsatellite markers, D10S541 and D10S1739. These two markers were informative in $77 \%$ and $66 \%$ of cases. However, in none of the patients investigated was any mono- or biallelic $\mathrm{LOH}$ found (data not shown).

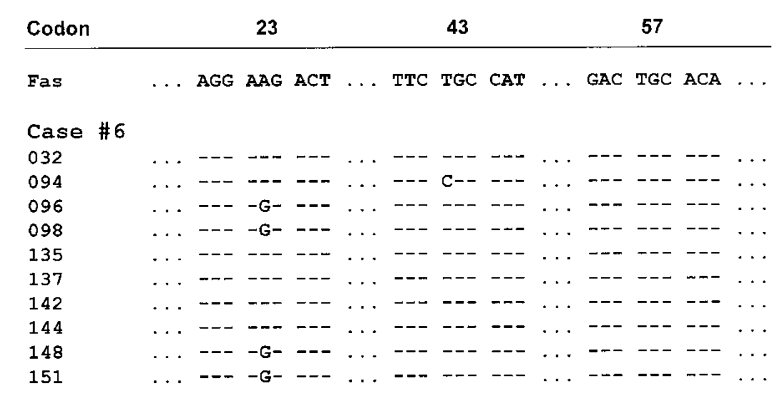

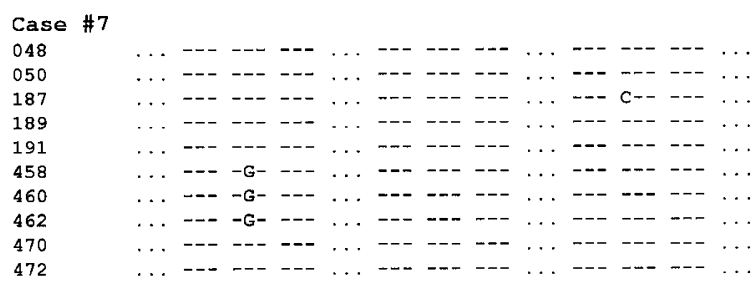

Figure 4.

Nucleotide sequence alignment of cloned Fas transcripts from malignant $B$ cells of Cases 6 and 7 . In the two patients, codon 23 is affected by the same mutation in multiple clones, whereas the codons 43 and 57 show randomized mutations only in one clone each. The normal Fas sequence and the numbering of codons is according to Itoh et al (1991).

\section{Discussion}

Recently, evidence emerged for a link between autoimmunity and non-Hodgkin's lymphomas (NHL), 
Table 1. Fas Mutations in Malignant B Cells from MALT-Type Lymphoma

\begin{tabular}{|c|c|c|c|c|}
\hline Codon ${ }^{a}$ & $\begin{array}{l}\text { Mutation } \\
\text { (Amino acid } \\
\text { change) }\end{array}$ & $\begin{array}{c}\text { Mutated } \\
\text { clones/normal } \\
\text { clones }\end{array}$ & $\begin{array}{l}\text { Case } \\
\text { No. }\end{array}$ & $\begin{array}{c}\text { Resistance } \\
\text { to } \\
\text { apoptosis }\end{array}$ \\
\hline 23 & $(\operatorname{Arg}) A \rightarrow G$ & $4 / 12$ & 6 & yes \\
\hline & (Lys $\rightarrow$ Arg) & $3 / 21$ & 7 & yes \\
\hline 27 & $\begin{array}{l}\mathrm{A} \rightarrow \mathrm{G} \\
\text { (silent) }\end{array}$ & $3 / 17$ & 5 & \\
\hline 50 & $\begin{aligned} \mathrm{G} & \rightarrow \mathrm{A} \\
\mathrm{Gly} & \rightarrow \mathrm{Ser}\end{aligned}$ & $2 / 18$ & 5 & yes \\
\hline 152 & $\begin{array}{c}\mathrm{G} \rightarrow \mathrm{T} \\
(\mathrm{Glu} \rightarrow \mathrm{STOP})\end{array}$ & $2 / 4$ & 9 & yes \\
\hline 172 & $\begin{aligned} \mathrm{T} & \rightarrow \mathrm{C} \\
\mathrm{Val} & \rightarrow \text { Ala }\end{aligned}$ & $2 / 14$ & 6 & yes \\
\hline 229 & $\begin{aligned} \mathrm{T} & \rightarrow \mathrm{C} \\
\mathrm{Val} & \rightarrow \text { Ala }\end{aligned}$ & $2 / 4$ & 9 & yes \\
\hline 237 & $\begin{array}{l}\mathrm{T} \rightarrow \mathrm{C} \\
\text { (silent) }\end{array}$ & 2/35 & 6 & \\
\hline 255 & $\begin{array}{l}A \rightarrow T \\
\text { (silent) }\end{array}$ & $2 / 4$ & 9 & \\
\hline 284 & $\begin{array}{l}\text { 1-bp insertion } \\
\text { (A) }\end{array}$ & $3 / 19$ & 1 & no \\
\hline 291 & $\begin{array}{l}\mathrm{A} \rightarrow \mathrm{G} \\
\text { (silent) }\end{array}$ & $\begin{array}{l}2 / 34 \\
3 / 21\end{array}$ & $\begin{array}{l}7 \\
6\end{array}$ & yes \\
\hline
\end{tabular}

Lys, lysine; Arg, arginine; Gly, glycine; Ser, serine; Glu, glutamic acid; STOP STOP-CODON; Val, valine; Ala, alanine.

${ }^{a}$ Numbering of codons is according to Itoh et al (1991).

which may be based on disturbances in Fas-mediated apoptosis (Plumas et al, 1998). MALT-type lymphomas of the thyroid gland, salivary gland, or the stomach show a strong association with organotropic autoimmune diseases that precede tumor development as initial lesion. Previous studies of a large panel of $B$ cell lymphomas demonstrated the presence of Fas mutations in some classical Hodgkin's cases (Müschen et al, 2000) and in different B cell NHLs, reporting Fas mutations in 16 of $150(11 \%)$ cases, with the highest incidence (60\%) among extranodal lymphoma (Gronbaek et al, 1998).

Therefore, we focused our study on lymphomas of MALT-type, the largest group within extranodal NHLs. We found 10 previously undescribed point mutations in Fas transcripts from malignant $B$ cells from four of five MALT-type lymphomas and from one of three DLBLs investigated. Because we have exclusively considered mutations that occurred in at least two independent Fas CDNA clones of the same patient or in different patients, we can rule out PCR artifacts. Six of 10 mutations lead to amino acid changes in the Fas protein and might thus have a potential functional relevance. Interestingly, five out of these mutations were found in malignant $B$ cells that were resistant to T cell-induced, Fas-mediated apoptosis.

The Fas mutations described herein are located both in the extra- and the intracellular domain of Fas and might therefore interfere with FasL binding (eg, mutation in codons 23 and 50) and Fas signaling (eg, mutation in codon 229). The 1-bp insertion (+A) after codon 284, found in a Fas-resistant and a Fas-sensitive case, more likely represents a DNA polymerase error resulting from a slippage mechanism in a run of identical nucleotides (Tindall and Kunkel, 1988) than a true mutation that would result in a truncated protein.

Although we could not detect Fas mutations in all cases resistant to apoptosis so far, our sequencing data, in combination with our functional data, support the idea of an association between Fas mutations and resistance to apoptosis. Because it was shown recently that mutated Fas proteins impair apoptosis in a dominant negative way (Siegel et al, 2000), this would also explain our finding that for each mutation only a minority of the Fas transcripts was affected.

However, factors other than Fas mutations could cause impairment of Fas-mediated apoptosis. One mechanism of protection could lie in the reduced Fas expression that was found in vivo in malignant cells of hematologic and nonhematologic origin (OwenSchaub et al, 1993) and in T cell leukemia cell lines in vitro (Martinez-Lorenzo et al, 1998). This mechanism appears not to be operative in MALT-type lymphoma, because all DLBLs that are resistant to apoptosis showed, not reduced, but rather enhanced constitutive Fas expression when compared with normal $B$ cells. Furthermore, those malignant $B$ cells from MALT-type lymphoma with the lowest Fas expression were sensitive to apoptosis.

A second mechanism of resistance to apoptosis described so far, is the production of soluble Fas (sFas) protein that antagonizes the normal function of Fas by the binding of FasL (Cheng et al, 1994). sFas is generated by alternative splicing of exon 6 coding for the transmembrane domain and was found in phytohemagglutinin-activated normal human lymphocytes (Cascino et al, 1995) from patients with autoimmune disease (Cheng et al, 1994) and in nonhematopoietic and lymphatic malignancies (Knipping et al, 1995; Midis et al, 1996; Yufu et al, 1998). Recently, sFas protein was found in the serum of some patients with MALT-type lymphoma (Doi et al, 1999), and it was speculated that it originates in the tumor cells. However, although we found mRNA for sFas in the purified malignant B cells from MALT-type lymphoma, this mRNA was not translated into protein, because sFas was completely absent in the tumor cells supernatants.

Resistance to apoptosis could also be due to impairment of the signaling cascade downstream of Fas, because it was shown recently in caspase- 3 or caspase-8 knockout-mice (Varfolomeev et al, 1998; Woo et al, 1999) and in a human T cell line defective in caspase-3 (Martinez-Lorenzo et al, 1998). However, we found caspase- 3 and caspase- 8 proteins and basic levels of PARP cleavage in MALT-type lymphomas, indicating that the signaling cascade is intact and facilitates spontaneous apoptosis without $T$ cell stimuli. This baseline apoptosis was abrogated after coculture with activated T cells, indicating cosignaling effects resulting from CD40-ligation (An and Knox, 
1996). Furthermore, the missing inducibility of caspase expression or processing under $\mathrm{T}$ cell influence is an additional clue to an impaired Fas molecule not transducing an apoptotic signal.

Fas mutations resulting in loss of function imply that Fas may act as a tumor suppressor gene. This hypothesis is supported by recent findings of genomic instability as detected by $\mathrm{LOH}$ in the Fas promotor region in solid tumors (Lee et al, 1999a, 1999b; Shin et al, 1999), but is in contrast to results with MALT-type lymphoma, because we could not find $\mathrm{LOH}$ in any of the cases investigated. However, hypermutation and ongoing mutations of MALT-type lymphoma antigen receptors support the notion that clonal growth of malignant B cells occurred during or after the germinal center development (Hallas et al, 1998; Qin et al, 1997). Therefore, it is possible that various Fas mutations, some of them resulting in loss of function and thus inhibition of apoptosis, may arise in mature B cells during variable, diverse, and joining gene segments (V[D]J) recombination and other diversification processes in the course of immune responses, as was shown recently for the bcl-6 gene (Peng et al, 1999; Shen et al, 1998). This would characterize the Fas mutations as an early event in MALT-type lymphomagenesis. The concept of dysregulated apoptosis in MALT-type lymphoma was supported by parallel examinations in the identification of specific chromosomal aberrations in these tumors. In particular, a rare $t(1 ; 14)(p 22 ; q 32)$ involves the apoptosis regulatory gene bcl-10 (Willis et al, 1999), and the more frequent translocation in MALT-type lymphomas t(11;18)(q21;q21) (Ott et al, 1997; Rosenwald et al, 1999) involves the apoptosis inhibitor gene HIAP-1 (Dierlamm et al, 1999). However, we found the $t(11 ; 18)$ in two of three MALT-type lymphomas resistant to apoptosis and also in two of four cases sensitive to apoptosis. Furthermore, although HIAP-1 was described to inhibit caspases directly (Roy et al, 1997), we found that caspases-3 and -8 were processed irrespective of the $t(11 ; 18)$. This indicates that the fusion protein HIAP-1/malt-type lymphoma-associated translocation (MLT) resulting from the $t(11 ; 18)$ may interfere with other apoptosis pathways. Additionally, the presence of $\mathrm{t}(11 ; 18)$ may not have an influence on the Fas mutation frequency, because there was no obvious difference between $\mathrm{t}(11 ; 18)$-positive $\left(2.35 \times 10^{-4} / \mathrm{bp}\right)$ and $\mathrm{t}(11 ; 18)$-negative MALT-type Iymphomas $(2.82 \times$ $\left.10^{-4} / \mathrm{bp}\right)$ compared with DLBL $\left(10.7 \times 10^{-4} / \mathrm{bp}\right)$.

Therefore our results characterize the $t(11 ; 18)$ as an additional event that may occur later in the course of MALT-type lymphomagenesis. Several events with similar consequences may join or interfere within MALT-type lymphomas, but ultimately they emphasize the principle of inhibition of apoptosis in MALTtype tumor pathogenesis.

\section{Materials and Methods}

\section{Patients}

Tumor specimens from patients with malignant lymphomas $(n=11)$ were obtained fresh from the tissues after surgical removal. Seven cases were diagnosed as MALT-type lymphomas and four cases as gastric DLBLs according to the revised European-American lymphoma (REAL) classification (Harris et al, 1994) (Table 2). The diagnosis was established by morphological and immunophenotypic analysis of freshfrozen and paraffin-embedded sections as described (Greiner and Müller-Hermelink, 1996). Reactive normal tonsillar tissues from routine tonsillectomy were used as a control.

The presence of the $t(11 ; 18)(q 21 ; q 21)$ in malignant $B$ cells was determined by applying a fluorescence in situ hybridization (FISH) assay that was recently developed to detect the chromosomal breakage in 11q21 in interphase cells (Rosenwald et al, 1999).

\section{Cell Preparation and Culture}

Small pieces of tumor tissue were pressed through sterile sieves. T and B cells from the resulting suspension were separated using magnetic beads coupled with antibodies (Dynal, Hamburg, Germany). T cells were isolated by using $\alpha$-CD3 beads and Detach-a-

Table 2. Characteristics of the Investigated Patients

\begin{tabular}{|c|c|c|c|c|c|c|}
\hline Case No. & Diagnosis/staging ${ }^{a}$ & Localization & Sex & Age & Apoptosis & $\mathrm{t}(11 ; 18)^{b}$ \\
\hline 1 & MALT/- & Parotis & $\mathrm{F}$ & 66 & Sensitive & No \\
\hline 2 & MALT/- & Parotis & $\mathrm{F}$ & 61 & Sensitive & No \\
\hline 3 & MALT/E I2 & Stomach & $\mathrm{M}$ & 59 & Sensitive & Yes \\
\hline 4 & MALT/- & Lung & 一 & - & Sensitive & Yes \\
\hline 5 & MALT/- & Thyroid & $M$ & 70 & Resistant & Yes \\
\hline 6 & MALT/- & Lung & - & - & Resistant & Yes \\
\hline 7 & MALT/- & Stomach & $\mathrm{F}$ & 69 & Resistant & No \\
\hline 8 & DLBL/E ॥1 & Stomach & $M$ & 74 & Resistant & No \\
\hline 9 & DLBL/E I2 & Stomach & $M$ & 31 & Resistant & No \\
\hline 10 & DLBL/- & Stomach & $M$ & 61 & Resistant & No \\
\hline 11 & DLBL/E III & Stomach & $M$ & 64 & Resistant & No \\
\hline
\end{tabular}

\footnotetext{
${ }^{a}$ Staging was done according to Musshoff modified by Radaszkiewicz et al (1992).

${ }^{b}$ Fluorescence in-situ hybridization (FISH) data according to Rosenwald et al (1999).

—, data not available; MALT, mucosa-associated lymphoid tissue; DLBL, diffuse large B cell lymphoma.
} 
beads thereafter (Dynal). B cells were depleted negatively by removing $T$ cells and macrophages with $\alpha$-CD2 and $\alpha$-CD14 beads, respectively. Malignant B cells were negatively purified from nonmalignant bystander B cells by using magnetic beads coupled with antibodies against the particular immunoglobulin light and heavy chains not expressed by the lymphoma as described in detail recently (Greiner et al, 1997). Normal memory B cells $\left(\mathrm{CD}_{19}{ }^{+}, \operatorname{lgM}^{+}, \mathrm{CD}^{-} 8^{-}, \operatorname{lgD}^{-}\right)$that were negatively depleted from human tonsils served as controls. Cells were cultured in flat-bottom 24-well plates in a final volume of $1 \mathrm{ml}$ at $37^{\circ} \mathrm{C}$ and $7 \% \mathrm{CO}_{2}$ in RPMI 1640 supplemented with gentamycin $(0.1$ $\mathrm{mg} / \mathrm{ml}$ ) and $10 \% \mathrm{FCS}$.

To investigate the interaction of malignant B cells with activated $\mathrm{T}$ cells, we established an experimental approach of an in vitro $\mathrm{B} / \mathrm{T}$ cell coculture. Heterologous $\mathrm{T}$ cells were activated for 6 hours by $\alpha$-CD3 stimulation using the monoclonal antibody 4B5 (Boehringer, Mannheim, Germany) presented by a murine fibroblast cell line that was transfected with human FcyRII (Banchereau and Rousset, 1991). Thereafter, those $T$ cells were cocultured in five-fold excess for 24 hours with malignant $B$ cells from MALT-type lymphoma and DLBL, respectively. Before performing RNA and protein extraction from B cells, the $T$ cells were removed immunomagnetically as described above. In general, each cell separation was checked on FACS, and cells were processed further if purity was above $95 \%$ in each setting. Epstein-Barr virus (EBV) cell lines from purified lymphoma B cells were generated (Cases 5 and 7) and served as independent controls for Fas sequencing.

\section{Preparation of RNA and cDNA Synthesis}

Total RNA was extracted either from $2 \times 10^{5}$ highly purified malignant or normal memory B cells using TRIzol reagent (Life Technologies, Paisley, United Kingdom) according to the manufacturer's instructions. First-strand cDNA synthesis was carried out with $1 \mu \mathrm{g}$ of total RNA as described in detail elsewhere (Knörr et al, 1999). The quality and amount of cDNA was estimated by PCR using glyceraldehyde-3phosphate dehydrogenase (GAPDH)-specific primers. $\mathrm{PCR}$ reactions were performed in the GeneAmp PCR system 2400 (Perkin-Elmer Cetus, Emeryville, California) in a final volume of $25 \mu$ l containing $1 \mu \mathrm{l}$ of cDNA, $2.5 \mu \mathrm{l}$ of $\times 10$ PCR buffer (Amersham Pharmacia,
Freiburg, Germany), $1.5 \mu \mathrm{ml}$ of $25 \mathrm{mM} \mathrm{MgCl}_{2}, 0.5 \mu \mathrm{l}$ of $10 \mathrm{~mm}$ dNTPs, $0.5 \mu \mathrm{l}$ of $20 \mathrm{pmol} / \mu \mathrm{l}$ of each primer and $0.5 \mathrm{U}$ of cloned Taq DNA polymerase (Amersham Pharmacia). Amplifications consisted of 20 cycles of denaturation at $94^{\circ} \mathrm{C}$ for 30 seconds, annealing of primers at $60^{\circ} \mathrm{C}$ for 30 seconds, extension of primers at $72^{\circ} \mathrm{C}$ for 45 seconds, and a final polymerization step of 4 minutes at $72^{\circ} \mathrm{C}$. PCR products were analyzed on a $2 \%$ agarose gel (Sigma, Deisenhofen, Germany), stained with ethidium bromide, and photographed under UV light.

\section{RT-PCR of Apoptosis-Relevant Genes}

For investigating the expression of apoptosis-relevant genes, two multiplex RT-PCR kits (hAPO-1 and hAPO-2; Maxim Biotech, San Francisco, California) were used. The hAPO-1 kit was designed for simultaneous analysis of caspase-1, c-myc, bcl-2, and p53, and the hAPO-2 kit for caspase-3, bcl-xL, bcl-2, bcl-xS, and bax. According to the manufacturer's instructions, the amplifications were as follows: 2 cycles ( $96^{\circ} \mathrm{C}$ for 1 minute, $60^{\circ} \mathrm{C}$ for 4 minutes) and 28 cycles $\left(94^{\circ} \mathrm{C}\right.$ for 1 minute, $60^{\circ} \mathrm{C}$ for 2,5 minutes) followed by a final polymerization step of 10 minutes at $70^{\circ} \mathrm{C}$.

\section{Cloning and Sequencing of Fas}

The entire coding region of Fas (1008 bp, accession no. M67454) was amplified in two steps by RT-PCR using the primer pairs CD95-I-For/CD95-GR46-Rev and CD95-GR19-For/CD95-III-Rev (Table 3). For the amplification we used a recombinant Taq DNA Polymerase (Amersham Pharmacia) that showed in our experimental system an error rate of $0.17 \%$ (C. Knörr, University of Würzburg, personal communication, 2000). The amplification consisted of initial denaturation at $94^{\circ} \mathrm{C}$ for 60 seconds followed by 33 cycles of denaturation at $94^{\circ} \mathrm{C}$ for 30 seconds, annealing of primers at $61^{\circ} \mathrm{C}$ for 30 seconds, extension of primers at $72^{\circ} \mathrm{C}$ for 60 seconds, and a final polymerization step at $72^{\circ} \mathrm{C}$ for 7 minutes. The PCR products were cloned into pCRscript (Stratagene, Heidelberg, Germany), which was used to transform ultracompetent Escherichia coli (Stratagene). White colonies were picked and grown overnight in $3 \mathrm{ml}$ of Luria-Bertani (LB) medium. The double-stranded DNA template from the colonies was sequenced by the chain-

Table 3. Primers Used for RT-PCR

\begin{tabular}{|c|c|}
\hline Primer & Sequence \\
\hline GAPDH For & 5'-GTG GAA GGA CTC ATG ACC ACA GTC-3' \\
\hline GAPDH Rev & 5'-CAT GTG GGC CAT GAG GTC CAC CAC-3' \\
\hline CD95-I-For ${ }^{a}$ & 5'-ATGCTGGGCATCTGGACCCT-3' \\
\hline CD95-GR46-Rev ${ }^{b}$ & 5'-CATTGACACCATTCTTTCGAA-3' \\
\hline CD95-GR19-For ${ }^{b}$ & 5'-AACATGCAGAAAGCACAGAAA-3' \\
\hline CD95-III-Rev ${ }^{a}$ & 5'-TCTAGACCAAGCTTTGGATTTC-3' \\
\hline
\end{tabular}

\footnotetext{
a Primers according to Fiucci and Ruberti; (1994)
}

${ }^{b}$ Primers according to Cascino et al (1996). 
terminating method (Sanger et al, 1977) using the Taq-dye-deoxy termination cycle sequencing kit (Applied Biosystems, Weiterstadt, Germany). Sequencing was performed on the ABI 373A automatic sequencer (Applied Biosystems).

\section{Detection of Loss of Heterozygosity}

Two polymorphic dinucleotide repeats flanking the Fas gene, D10S541 and D10S1739, in a distance of 1.2 centimorgans (cM) were chosen from the Genome Data Base (GDB Human Genome Database, 2001) and primers synthesized according to the sequences provided. The $5^{\prime}$ ends of the forward primers were labeled with fluorescent dyes HEX and FAM, respectively (PE Biosystems, Weiterstadt, Germany). PCRs were performed as described in detail elsewhere (Starostik et al, 2000). PCR products were electrophoresed on a $4.5 \%$ polyacrylamide gel containing $45 \%$ urea for 2-3 hours at $150 \mathrm{~W}$ on the ABI 377 Sequencer (Applied Biosystems).

\section{Protein Extraction and Immunoblotting}

Total protein was extracted from $1 \times 10^{6}$ highly purified malignant or normal memory B cells as described (Laemmli, 1970). Proteins were resolved in SDS-PAGE, transferred to nitrocellulose membranes (Schleicher \& Schuell, Dassel, Germany), and incubated with primary rabbit antibody $(1 \mu \mathrm{g} / \mathrm{ml})$ for 1 hour at room temperature followed by a secondary $\alpha$-rabbit antibody linked to horseradish peroxidase (Amersham, Braunschweig, Germany). Signals were visualized by enhanced chemoluminescence (ECL, Amersham) according to the manufacturer's instructions. The following primary antibodies were used (all from Santa Cruz, Heidelberg, Germany): $\alpha$-caspase-3 (N19), $\alpha$-caspase-8 (T-16), and $\alpha$-Poly-ADP Ribose Polymerase (PARP, $\mathrm{H}-250)$.

\section{Immunoprecipitation}

Cell culture supernatant (800-1000 $\mu \mathrm{l})$ of normal and malignant $B$ cells was incubated for 1 hour at $4^{\circ} \mathrm{C}$ with $1 \mu \mathrm{g}$ of $\alpha$-sFas antibody (G 254-274; Pharmingen, Hamburg, Germany). As a positive control, $100 \mathrm{ng}$ of recombinant human sFas (Pharmingen) were diluted in $1000 \mu \mathrm{l}$ cell culture medium and treated accordingly. Then Protein A/G-agarose (Santa Cruz, Heidelberg, Germany) was added to the samples and the same incubation step was repeated. The proteins were precipitated by centrifugation, washed, resolved in Laemmli buffer without reducing agents such as dithiothreitol (DTT), and subjected to SDS-PAGE. Immunoblotting was carried out with the same antibody (G 254-274) that was used for precipitation.

\section{Flow Cytometry}

Three-color flow cytometric analysis was performed with a FACScan (Becton Dickinson, Mountain View, California) using the program LYSIS II for data acquisition and analysis. For investigating $B$ cells, the instrument was set up by locating the B cells of an unstained sample in a standard position in the display of forward and sideward light scattering by adjustment of the light-scattering detectors. Thereafter samples stained with fluorescein-isothiocyanate (FITC)-, phycoerythrin (PE)-, and Quantum Red (QR)-conjugated CD19 antibodies were measured. To avoid spectral overlappings between the three fluorescence channels, the fluorescence detectors were adjusted accordingly.

The following antibodies were used: $\alpha$-CD19-FITC (F 768; Dako, Hamburg, Germany), $\alpha$-CD19-PE (M 740, Dako), $\alpha$-CD19-QR (MHCD 1906; MEDAC, Hamburg, Germany), and $\alpha$-APO-1-PE (kind gift from P. Krammer, Deutsches Krebsforschungszentrum, Heidelberg). A corresponding isotype control was also measured for each antibody: IgG1-FITC (F-6397; Sigma Chemical Co., St. Louis, Missouri), IgG1-PE (P4685, Sigma), and IgG1-QR (MG106TC, MEDAC).

To measure apoptosis, the DNA-binding reagent, 7-amino actinomycin D (7-AAD), was used as described elsewhere (Philpott et al, 1996). In samples of $\mathrm{B} / \mathrm{T}$ cell coculture, only cells positive for CD19 (B cells) were analyzed for 7-AAD binding and Fas expression. At least 40,000 cells were recorded for a FACS analysis. [Editor: Author has cited the following references in tables: Cascino et al, 1996; Fiucci and Ruberti, 1994; Radaszkiewicz et al, 1992.]

\section{Acknowledgements}

We would like to thank Christa Amrehn, Maria Reichert, Simone Schindelmann, and Erwin Schmitt for their expert technical assistance.

\section{References}

An S and Knox KA (1996). Ligation of CD40 rescues RamosBurkitt lymphoma B cells from calcium ionophore- and antigen receptor-triggered apoptosis by inhibiting activation of the cysteine protease CPP32/Yama and cleavage of its substrate PARP. FEBS Lett 386:115-122.

Banchereau J and Rousset F (1991). Growing human B lymphocytes in the CD40 system. Nature 353:678-679.

Bettinardi A, Brugnoni D, Quiros-Roldan E, Malagoli A, La Grutta S, Correra A, and Notarangelo LD (1997). Missense mutations in the Fas gene resulting in autoimmune lymphoproliferative syndrome: A molecular and immunological analysis. Blood 89:902-909.

Cascino I, Fiucci G, Papoff G, and Ruberti G (1995). Three functional soluble forms of the human apoptosis-inducing Fas molecule are produced by alternative splicing. $\mathrm{J}$ Immunol 154:2706-2713.

Cascino I, Papoff G, De Maria R, Testi R, and Ruberti G (1996). Fas/Apo-1 (CD95) receptor lacking the intracytoplasmic signaling domain protects tumor cells from Fasmediated apoptosis. J Immunol 156:13-17.

Cheng J, Zhou T, Liu C, Shapiro JP, Brauer MJ, Kiefer MC, Barr PJ, and Mountz JD (1994). Protection from Fasmediated apoptosis by a soluble form of the Fas molecule. Science 263:1759-1762. 
Deveraux QL and Reed JC (1999). IAP family proteins: Suppressors of apoptosis. Genes Dev 13:239-252.

Deveraux QL, Roy N, Stennicke HR, Van Arsdale T, Zhou Q, Srinivasula SM, Alnemri ES, Salvesen GS, and Reed JC (1998). IAPs block apoptotic events induced by caspase-8 and cytochrome $\mathrm{c}$ by direct inhibition of distinct caspases. Embo J 17:2215-2223.

Dierlamm J, Baens M, Wlodarska I, Stefanova-Ouzounova M, Hernandez JM, Hossfeld DK, De Wolf-Peeters C, Hagemeijer A, Van den Berghe $H$, and Marynen $P$ (1999). The apoptosis inhibitor gene API2 and a novel $18 \mathrm{q}$ gene, MLT, are recurrently rearranged in the $t(11 ; 18)(q 21 ; q 21)$ associated with mucosa- associated lymphoid tissue lymphomas (in process citation). Blood 93:3601-3609.

Doi T, Nishikawa Y, Endo H, Hosokawa Y, Tanimizu M, and Hyodo I (1999). Serum soluble Fas antigen in gastric MALT (mucosa-associated lymphoid tissue) lymphoma patients (in process citation). J Exp Clin Cancer Res 18:343-345.

Fisher GH, Rosenberg FJ, Straus SE, Dale JK, Middleton LA, Lin AY, Strober W, Lenardo MJ, and Puck JM (1995). Dominant interfering Fas gene mutations impair apoptosis in a human autoimmune lymphoproliferative syndrome. Cell 81:935-946.

Fiucci G and Ruberti G (1994). Detection of polymorphisms within the Fas cDNA gene sequence by GC-clamp denaturing gradient gel electrophoresis. Immunogenetics 39:437439.

GDB Human Genome Database (2001). Toronto, Canada: The Hospital for Sick Children; Baltimore, MD: Johns Hopkins University, 1990-. Updated daily. Available from Internet at http://www.gdb.org/.

Goodnow CC (1996). Balancing immunity and tolerance: Deleting and tuning lymphocyte repertoires. Proc Natl Acad Sci USA 93:2264-2271.

Greiner A, Knörr C, Qin Y, Schultz A, Marx A, Kroczek RA, and Müller-Hermelink HK (1998). CD40 ligand and autoantigen are involved in the pathogenesis of low-grade B-cell lymphomas of mucosa-associated lymphoid tissue (in process citation). Dev Immunol 6:187-195.

Greiner A, Knörr C, Qin Y, Sebald W, Schimpl A, Banchereau J, and Müller-Hermelink HK (1997). Low-grade B cell lymphomas of mucosa-associated lymphoid tissue (MALT-type) require CD40-mediated signaling and Th2-type cytokines for in vitro growth and differentiation. Am J Pathol 150:15831593.

Greiner A and Müller-Hermelink HK (1996). Recent advances in gastric extranodal B-cell lymphoma. Curr Diagn Pathol 3:91-98.

Gronbaek K, Straten PT, Ralfkiaer E, Ahrenkiel V, Andersen MK, Hansen NE, Zeuthen J, Hou-Jensen K, and Guldberg P (1998). Somatic Fas mutations in non-Hodgkin's lymphoma: Association with extranodal disease and autoimmunity. Blood 92:3018-3024.

Hallas C, Greiner A, Peters K, and Müller-Hermelink HK (1998). Immunoglobulin VH genes of high-grade mucosaassociated lymphoid tissue lymphomas show a high load of somatic mutations and evidence of antigen-dependent affinity maturation. Lab Invest 78:277-287.

Harris NL, Jaffe ES, Stein H, Banks PM, Chan JK, Cleary ML, Delsol G, De Wolf Peeters C, Falini B, and Gatter KC (1994). A revised European-American classification of lymphoid neoplasms: A proposal from the International Lymphoma Study Group (see comments). Blood 84:1361-1392.

Hussell T, Isaacson PG, Crabtree JE, and Spencer J (1996). Helicobacter pylori-specific tumour-infiltrating $T$ cells provide contact dependent help for the growth of malignant B cells in low-grade gastric lymphoma of mucosa-associated lymphoid tissue (see comments). J Pathol 178:122-127.

Itoh $\mathrm{N}$, Yonehara $\mathrm{S}$, Ishii $\mathrm{A}$, Yonehara $\mathrm{M}$, Mizushima $\mathrm{S}$, Sameshima M, Hase A, Seto $Y$, and Nagata S (1991). The polypeptide encoded by the cDNA for human cell surface antigen Fas can mediate apoptosis. Cell 66:233-243.

Knipping E, Debatin KM, Stricker K, Heilig B, Eder A, and Krammer PH (1995). Identification of soluble APO-1 in supernatants of human B- and T-cell lines and increased serum levels in B- and T-cell leukemias. Blood 85:1562-1569.

Knörr C, Amrehn C, Seeberger H, Rosenwald A, Stilgenbauer S, Ott G, Müller-Hermelink HK, and Greiner A (1999). Expression of costimulatory molecules in low-grade mucosaassociated lymphoid tissue-type lymphomas in vivo. Am J Pathol 155:2019-2027.

Laemmli UK (1970). Cleavage of structural proteins during the assembly of the head of bacteriophage T4. Nature 227:680-685.

Lee SH, Shin MS, Park WS, Kim SY, Dong SM, Pi JH, Lee HK, Kim HS, Jang JJ, Kim CS, Kim SH, Lee JY, and Yoo NJ (1999a). Alterations of Fas (APO-1/CD95) gene in transitional cell carcinomas of urinary bladder. Cancer Res 59:30683072 .

Lee SH, Shin MS, Park WS, Kim SY, Kim HS, Han JY, Park GS, Dong SM, Pi JH, Kim CS, Kim SH, Lee JY, and Yoo NJ (1999b). Alterations of Fas (Apo-1/CD95) gene in non-small cell lung cancer. Oncogene 18:3754-3760.

Martinez-Lorenzo MJ, Gamen S, Etxeberria J, Lasierra P, Larrad L, Pineiro A, Anel A, Naval J, and Alava MA (1998). Resistance to apoptosis correlates with a highly proliferative phenotype and loss of Fas and CPP32 (caspase-3) expression in human leukemia cells. Int J Cancer 75:473-481.

Midis GP, Shen Y, and Owen-Schaub LB (1996). Elevated soluble Fas (sFas) levels in nonhematopoietic human malignancy. Cancer Res 56:3870-3874.

Müschen M, Re D, Brauninger A, Wolf J, Hansmann ML, Diehl V, Küppers R, and Rajewski K (2000). Somatic mutations of the CD95 gene in Hodgkin and Reed-Sternberg cells. Cancer Res 60:5640-5643.

Nagata S (1997). Apoptosis by death factor. Cell 88:355-365.

Ott G, Katzenberger T, Greiner A, Kalla J, Rosenwald A, Heinrich U, Ott MM, and Müller-Hermelink HK (1997). The $\mathrm{t}(11 ; 18)(\mathrm{q} 21 ; \mathrm{q} 21)$ chromosome translocation is a frequent and specific aberration in low-grade but not high-grade malignant non-Hodgkin's lymphomas of the mucosaassociated lymphoid tissue (MALT-) type. Cancer Res 57: 3944-3948.

Owen-Schaub LB, Meterissian S, and Ford RJ (1993). Fas/ APO-1 expression and function on malignant cells of hematologic and nonhematologic origin. J Immunother 14:234241.

Peng HZ, Du MQ, Koulis A, Aiello A, Dogan A, Pan LX, and Isaacson PG (1999). Nonimmunoglobulin gene hypermutation in germinal center B cells. Blood 93:2167-2172. 
Philpott NJ, Turner AJ, Scopes J, Westby M, Marsh JC, Gordon-Smith EC, Dalgleish AG, and Gibson FM (1996). The use of 7-amino actinomycin D in identifying apoptosis: Simplicity of use and broad spectrum of application compared with other techniques. Blood 87:2244-2251.

Plumas J, Jacob MC, Chaperot L, Molens JP, Sotto JJ, and Bensa JC (1998). Tumor B cells from non-Hodgkin's lymphoma are resistant to CD95 (Fas/Apo-1)-mediated apoptosis. Blood 91:2875-2885.

Qin Y, Greiner A, Hallas C, Haedicke W, and MüllerHermelink HK (1997). Intraclonal offspring expansion of gastric low-grade MALT-type lymphoma: Evidence for the role of antigen-driven high-affinity mutation in lymphomagenesis. Lab Invest 76:477-485.

Radaszkiewicz T, Dragosics B, and Bauer P (1992). Gastrointestinal malignant lymphomas of the mucosa-associated lymphoid tissue: Factors relevant to prognosis. Gastroenterology 102:1628-1638.

Rathmell JC, Townsend SE, Xu JC, Flavell RA, and Goodnow CC (1996). Expansion or elimination of B cells in vivo: Dual roles for CD40-and Fas (CD95)-ligands modulated by the B cell antigen receptor. Cell 87:319-329.

Rieux Laucat F, Le Deist F, Hivroz C, Roberts IA, Debatin KM, Fischer A, and de Villartay JP (1995). Mutations in Fas associated with human lymphoproliferative syndrome and autoimmunity. Science 268:1347-1349.

Rosenwald A, Ott G, Stilgenbauer S, Kalla J, Bredt M, Katzenberger T, Greiner A, Ott MM, Gawin B, Dohner H, and Müller-Hermelink HK (1999). Exclusive detection of the $t(11$; 18)(q21;q21) in extranodal marginal zone B cell lymphomas (MZBL) of MALT type in contrast to other MZBL and extranodal large B cell lymphomas. Am J Pathol 155:1817-1821.

Roy N, Deveraux QL, Takahashi R, Salvesen GS, and Reed JC (1997). The C-IAP-1 and C-IAP-2 proteins are direct inhibitors of specific caspases. Embo J 16:6914-6925.

Sanger F, Nicklen S, and Coulson AR (1977). DNA sequencing with chain-terminating inhibitors. Proc Natl Acad Sci USA 74:5463-5467.

Shen HM, Peters A, Baron B, Zhu X, and Storb U (1998). Mutation of BCL- 6 gene in normal $B$ cells by the process of somatic hypermutation of Ig genes. Science 280:1750-1752.

Shin MS, Park WS, Kim SY, Kim HS, Kang SJ, Song KY, Park JY, Dong SM, Pi JH, Oh RR, Lee JY, Yoo NJ, and Lee SH (1999). Alterations of Fas (Apo-1/CD95) gene in cutaneous malignant melanoma. Am J Pathol 154:1785-1791.

Siegel RM, Frederiksen JK, Zacharias DA, Chan FK, Johnson M, Lynch D, Tsien RY, and Lenardo MJ (2000). Fas preassociation required for apoptosis signaling and dominant inhibition by pathogenic mutations (see comments). Science 288 : 2354-2357.
Sneller MC, Wang J, Dale JK, Strober W, Middelton LA, Choi Y, Fleisher TA, Lim MS, Jaffe ES, Puck JM, Lenardo MJ, and Straus SE (1997). Clinical, immunologic, and genetic features of an autoimmune lymphoproliferative syndrome associated with abnormal lymphocyte apoptosis. Blood 89:1341-1348.

Starostik P, Greiner A, Schultz A, Zettl A, Peters K, Rosenwald A, Kolve M, and Müller-Hermelink HK (2000). Genetic aberrations common in gastric high-grade large B-cell lymphoma. Blood 95:1180-1187.

Suda T, Takahashi T, Golstein P, and Nagata S (1993). Molecular cloning and expression of the Fas ligand, a novel member of the tumor necrosis factor family. Cell 75:11691178.

Takahashi T, Tanaka M, Brannan Cl, Jenkins NA, Copeland NG, Suda T, and Nagata S (1994). Generalized lymphoproliferative disease in mice, caused by a point mutation in the Fas ligand. Cell 76:969-976.

Tindall KR and Kunkel TA (1988). Fidelity of DNA synthesis by the Thermus aquaticus DNA polymerase. Biochemistry 27: 6008-6013.

Varfolomeev EE, Schuchmann M, Luria V, Chiannilkulchai N, Beckmann JS, Mett IL, Rebrikov D, Brodianski VM, Kemper OC, Kollet O, Lapidot T, Soffer D, Sobe T, Avraham KB, Goncharov T, Holtmann H, Lonai P, and Wallach D (1998). Targeted disruption of the mouse Caspase 8 gene ablates cell death induction by the TNF receptors, Fas/Apo1, and DR3 and is lethal prenatally. Immunity 9:267-276.

Watanabe-Fukunaga $\mathrm{R}$, Brannan $\mathrm{Cl}$, Copeland NG, Jenkins NA, and Nagata S (1992). Lymphoproliferation disorder in mice explained by defects in Fas antigen that mediates apoptosis. Nature 356:314-317.

Willis TG, Jadayel DM, Du MQ, Peng H, Perry AR, Abdul-Rauf $M$, Price $H$, Karran L, Majekodunmi O, Wlodarska I, Pan L, Crook T, Hamoudi R, Isaacson PG, and Dyer MJ (1999). Bcl10 is involved in $t(1 ; 14)(p 22 ; q 32)$ of MALT $B$ cell lymphoma and mutated in multiple tumor types. Cell 96:35-45.

Woo M, Hakem A, Elia AJ, Hakem R, Duncan GS, Patterson BJ, and Mak TW (1999). In vivo evidence that caspase-3 is required for Fas-mediated apoptosis of hepatocytes. J Immunol 163:4909-4916.

Yufu Y, Choi I, Hirase N, Tokoro A, Noguchi Y, Goto T, Uike $\mathrm{N}$, and Kozuru M (1998). Soluble Fas in the serum of patients with non-Hodgkin's lymphoma: Higher concentrations in angioimmunoblastic T-cell lymphoma. Am J Hematol 58: 334-336. 